\title{
THE FUNCTIONS OF APEC AND IMPLICATIONS FOR CHINA: A CRITICAL REVIEW
}

\section{ZHANG IIANIUN}

Asia Pacific Economic Cooperation (APEC) is experiencing a critical time in its short history. Founded in 1989, APEC includes all the major economies of the region and the most dynamic, fastest growing economies in the world and claims to be a major contributor to global prosperity and stability. Its 18 members had a combined GDP of over US\$16 trillion in 1995, and 42 per cent of global trade. With the arrival of the new millenium, there are some key questions to ask. Ten years after its establishment, is APEC able to deliver? What are the factors behind its present situation? What will be APEC's future configuration and activities? How will China cope with APEC's trade and investment agenda? There are many questions that remain to be answered.

This chapter analyses APEC's evolving features and functions, and its achievements and pitfalls. It examines the significance of APEC to China, China's attitude towards APEC's trade and investment liberalisation process, and the interactions between China and APEC under the trend of increasing globalisation and economic interdependence. Finally, it underlines the key issues that need be addressed by APEC in the long term.

\section{HISTORICAL REVIEW}

Throughout the 1980s, the economies of the Asian members of APEC grew at rates substantially higher than those of Europe and North America. Partly created and accelerated by increasing foreign direct investment from Japan, Asia's trade and investment tends to be more concentrated within the region. With widespread anxiety about emerging regional trading arrangements elsewhere in the world, Asian economies - which are mostly export-oriented-considered setting-up their own arrangement in the event that regional arrangements elsewhere became 
inward-looking trading blocs. ${ }^{1}$ Meanwhile, frustrated with the slow progress of the Uruguay Round negotiations of the General Agreement on Tariffs and Trade (GATT), the United States resorted to regionalism and promoted the establishment of the North American Free Trade Agreement (NAFTA). In 1993, it offered to host the first economic leaders' meeting of APEC, and thus created a new dimension of Asia Pacific cooperation. It was believed that the creation of APEC would serve to maintain an open international trading regime and reduce the growing number of trade disputes involving APEC members. Moreover, APEC would help enhance the process of economic integration and exchange of views among APEC members and promote a positive conclusion of the Uruguay Round negotiations of the GATT (Janow 1997:951).

The establishment of APEC has been described as 'like-minded people [meeting] together' to engage in trade and investment liberalisation and economic cooperation in Asia and the Pacific region. While not devoid of political content, it is safe to say that APEC has developed primarily in response to the growing interdependence among Asia Pacific economies (Janow 1997:991).

\section{DISTINCTIVE FEATURES}

Over the years, APEC has developed a number of unique features and decisionmaking processes that differenentiate it from any other international or regional forum. To start with, APEC is neither a formalised free-trade arrangementsuch as NAFTA - nor anything like a European-style common market. Instead it has coined the unique term of 'open regionalism' to describe its approach to trade and economic issues (Janow 1997). In other words, APEC has committed to offer the liberalisation it has achieved to non-members on a non-discriminatory basis. This was designed to avoid the inherently preferential nature of free trade arrangements and the deleterious effect of the proliferation of such an arrangement on the newly formed World Trade Organization (WTO).

It was agreed that APEC would be a non-formal forum for consultations among high-level representatives of APEC economies on matters of common interest and concern. Therefore, it is not surprising to note that the economic leaders' meeting is usually prefixed with the word 'informal', and all rules and principles adopted by APEC are labeled as 'non-binding', such as 'Non-Binding Investment Principles' and 'Non-Binding Principles on Government Procurement'.

Diversity is an important feature of APEC, which now consists of 21 member economies with rich differences in terms of political system, cultural background, religious beliefs, and population size as well as level of economic development. This diversity can be interpreted as both a source of action and-more frequently - hindrance to quick decisions and actions. 
Recognising the diverse interests and circumstances of its membership, APEC has developed new approaches to solving its problems, the 'APEC approach'. Thus far there is no clear definition of this term, but in practice people most often refer to it in the following circumstances.

- Consensus. Consensus constitutes the core element of APEC's decisionmaking process. This means every member has de facto veto power over any proposal. To date, this principle has been strictly adhered to over the course of APEC activities. During the deliberation of Early Voluntary Sectoral Liberalisation (EVSL), however, the term 'critical mass' or the (then) '18 minus X' formula was introduced. This means further sectoral liberalisation can proceed through a plurilateral agreement among a group of APEC economies if a 'critical mass' exists in its favour. This formula directly contradicts the principle of consensus and still remains controversial.

- Concerted unilateralism. This refers to the fact that with commonly agreed targets and principles each APEC country should take unilateral actions through voluntary steps. APEC's liberalisation program is supposed to be reflected in the Individual Action Plans (IAPs) and Collective Action Plans (CAPs). APEC is expected to strengthen liberalisation initiatives through a combination of multilateral, regional and unilateral actions.

- Top-down direction. This is another newly developed approach in response to the slow progress achieved thus far. Some significant issues like the EVSL and the Information Technology Agreement (ITA) were directly handed over to ministers and leaders who meet annually, instead of first spending time with the cautious working-level officials. This approach has proved to be a very powerful weapon, as justifications have to be made for the annual summit, and this method makes APEC more resultsoriented.

\section{SIGNIFICANT STEPS}

APEC has come a long way since 1989. From the initial stage of exchanging views and project-based initiatives, it has been transformed into a forum of greater substance and higher purpose. At Blake Island in November 1993, when the leaders met for the first time for informal discussions, they envisioned a community of Asia Pacific economies in which the energy of diversity would be harnessed, the spirit of openness and partnership would be deepened and dynamic growth would be sustained through cooperative efforts (in Seattle 1993). In 1994 in Bogor, Indonesia, leaders translated the vision of an open trade system into the ambitious goal of free and open trade and investment in the Asia Pacific by 2010 for developed members and 2020 for developing members (in Bogor 1994). In Osaka in 1995, APEC leaders adopted a framework for achieving their goal- 
the Osaka Action Agenda (OAA) - which establishes the three pillars of APEC activities: trade and investment liberalisation (TLF), business facilitation and economic and technical cooperation (ecotech). OAA also clearly spelled out the general principles for liberalisation and facilitation and essential elements for economic and technical cooperation (in Osaka 1995).

The Manila Action Plan for APEC (MAPA) adopted by economic leaders in 1996 includes the LAPs and CAPs and progress reports on the joint activities of all APEC economies in their endeavour to achieve the goal set out in Bogor. The leaders also outlined six priorities for economic and technical cooperation: developing human capital, fostering safe and efficient capital markets, strengthening economic infrastructure, harnessing technologies of the future, promoting environmentally sustainable growth, and encouraging the growth of small and medium-sized enterprises. At their Vancouver meeting in 1997, economic leaders reaffirmed their commitment to update their IAPs annually and adopted the 15 sectors for early sectoral liberalisation, with nine to be advanced throughout 1998 and implementation to occur in $1999 .^{2}$ They also encouraged more active participation of the business community, young people, women and civil society. Leaders endorsed 'The Blueprint for APEC Customs Modernisation' as a model for business facilitation as well as the 'Vancouver Framework for Enhanced PublicPrivate Partnership for Infrastructure Development'. Electronic commerce was discussed for the first time and instructions were made on the development of a work program (in Vancouver 1997). ${ }^{3}$

At their Kuala Lumpur meeting in 1998, APEC leaders committed to work together to pursue a cooperative growth strategy to end the financial crisis that had engulfed the region. They agreed to seek an EVSL agreement with nonAPEC members at the WTO, and pledged to strengthen social safety nets, financial systems, trade and investment flows, the scientific and technological base, human resources development, economic infrastructure, and business and commercial links to provide a firm basis for sustained growth into the twenty-first century (Kuala Lumpur 1998). At the Auckland meeting in September 1999, leaders endorsed new APEC Principles to Enhance Competition and Regulatory Reform, further work on an APEC Food System, and agreed to give priority to trade facilitation in 2000 . They also pledged to strengthen domestic financial markets and improve the international framework governing the flow of international trade and investment (in Auckland 1999). ${ }^{4}$

When assessing the progress of APEC, it must be recognised that APEC has made remarkable progress through members' voluntary and unilateral actions as well as collective initiatives on trade and investment liberalisation and facilitation. APEC members have lowered their average tariff levels by almost half from 15 to 9 per cent. Many developing members such as Chile, China, Thailand and the Philippines experienced a dramatic decline in their average tariff levels. Now 14 members have tariff levels below 15 per cent with the majority of these below 10 
per cent. Three members have average tariff rates at close to zero (PECC 1996). Greater transparency on non-tariff measures has been enhanced through identification and removal exercises. With respect to investment, members commit to review their investment regimes for investment liberalisation and voluntarily include in their IAPs, wherever possible, the list of specific options to be developed by the Investment Expert Group. The annual investment symposium facilitates APEC's investment reform process and improvement of the investment environment in the APEC region. In terms of services, few APEC economies impose barriers on foreign providers of computer, telecommunication or tourism services (PECC 1995). Three sectors--education, distribution and business services - have been identified as priority sectors to compile a list of measures affecting trade in services. An APEC Directory on Professional Services, covering accountancy, architecture and engineering is under development. A list of existing databases containing statistical information on trade in services has been compiled, and trade in services arrangements within APEC have been reviewed.

In other areas such as customs procedures, intellectual property rights, dispute mediation, competition policy and deregulation, contact points were established, databases on government laws and regulations were set up, various training programs were conducted to enhance members' understanding, and commitments were made by members to further liberalise their domestic regimes and to facilitate business transactions. A set of non-binding principles on government procurement is under active discussion to be concluded one year in advance by 1999. Various working groups under ecotech have undertaken similar kinds of activities. In addition, the creation of a senior officials meeting, a 'Subcommittee on Economic and Technical Cooperation' (ESC) to coordinate and oversee APEC's ecotech activities will add new impetus to the implementation of the 1996 'Manila Declaration on an APEC Framework for Strengthening Economic Cooperation and Development'.

\section{REGRETTABLE LOOPHOLES}

While recognising the achievements of APEC, it must be said that APEC has failed to live up to all expectations. It is facing a reputation problem. Critics charge that 'APEC has policies aplenty, but few implemented'. Others describe APEC as a 'talk shop'. Checking the grand CAPs, it is easy to agree with the accusations: ten years after its founding, most APEC activities still remain at the stage of dialogue and information exchange. All the action plans look impressive, but there is nothing substantial. According to its work program, APEC was supposed to begin implementation in 1997. Concrete outcomes are yet to occur.

Except for its slow progress on trade and investment liberalisation and facilitation, APEC has yet to prove its value, inter alia, in the following areas. 
APEC failed to act swiftly and responsively to the East Asian financial crisis that severely affected 12 of its 21 member economies. From 1997 throughout 1998, APEC, apart from rhetoric, undertook no serious concrete actions

APEC as the most powerful forum in the Asia Pacific region, could have played a much more significant role in taking collaborative action to alleviate the crisis and sending the right signals to the international community with respect to the region's economic stability and growth. The crisis is the Asia Pacific's own problem; it is too important for APEC to stand aloof.

Economic and technical cooperation has been recognised as one of the three pillars of APEC and should be given equal attention. But in reality, ecotech has been overshadowed by the trade and investment liberalisation and facilitation process. This has caused frustration and reduced interest in liberalisation among developing economies. In many cases, the first priority of the developing members is economic development, and to achieve that, they need infrastructure, technology and knowledge. But now there is growing concern that APEC's ecotech agenda is too business-biased and is looking increasingly like trade facilitation rather than economic cooperation among the governments. This is partly due to the reluctance of some developed members to offer contributions to the process.

While APEC's approach to ecotech differs from the traditional 'foreign aid' system, it does not exclude member governments from taking specific actions. ${ }^{5}$ Actually, trade and investment liberalisation and ecotech are mutually and equally reinforcing. Ecotech provides APEC with a feature that distinguishes from the WTO, which only offers developing economies a delayed phrasingin of obligations. A successful program on ecotech will help foster the confidence building among APEC members and enable the developing economies to benefit from market opening initiatives. As well, it is as important in building domestic political support for reform, or in some cases countering opposition for more liberal economic policies. Therefore it is not surprising that developing members hold high expectations of the newly formed ESC to address their concerns.

In economic and financial turmoil such as the crisis, many people start to doubt the benefits of globalisation and liberalisation. Some argue that the causes of the East Asian crisis were directly related to the free trade and investment policies of their governments, and thus call for policy changes. APEC needs to develop sound outreach strategies towards the community, to inform them about the benefits of liberalisation as well as associated adjustment costs. Only when this issue has been properly tackled can APEC make further progress towards liberalisation. In this juncture, the project on the impact of liberalisation undertaken by Australia is crucial in addressing these problems.

APEC's lack of tangible outcomes is causing angst among business people. On the one hand, this is partly due to insufficient communication with the business community, and on the other hand, it reflects APEC's failure to provide 
convincing outcomes in the short-term. In a sense, the EVSL process, which was supposed to be implemented in 1999, posed a great challenge for APEC to prove its worth and effectiveness. The end result was discouraging-after hot debate, EVSL implementation was transferred to the WTO.

\section{FUNCTIONAL BARRIERS}

It is appropriate to ask why APEC is not functioning as envisaged. There are a number of reasons, among which the following could be identified as the most important.

- Traumatic political and economic situation. APEC is now at a critical time and strong leadership is badly needed. However, the actual situation of APEC members is problematic. While East Asian countries-in particular Korea-have been struggling with the worst economic crisis of the 1990s, Japan is trapped in economic sluggishness. Prime Minister Obuchi proved the effectiveness of the government stimulus measures in its bid to save the ravaged financial system. President Clinton, running to the end of his term in his office, has been severely restrained by the Republican dominated Congress in any major initiatives. President Wahid of Indonesia is buried with ceaseless domestic unrest and massive economic problems. China has been locked in government restructuring, shrinking export and foreign investment, and an increasing rate of unemployment. Affected by Russian economic turbulence, Latin American countries are starting to experience economic slow-down. With APEC's steering team in such a poor shape, the Kuala Lumpur summit had difficulty in producing anything significant.

- Embedded structural problems. As revealed by the EVSL process, APEC has no implementation mechanism. None of its decisions are legally binding, which allows its members leeway in non-performance. Most of APEC's actions are carried out through unilateral and voluntary steps. There is no supra-national authority to administer or develop rules. With respect to the IAPs - the main channel for trade and investment liberalisation - the only existing mechanism is through voluntary peer review, which cannot guarantee faithful and effective enforcement and improvement of the IAPs. Moreover, APEC's decision-making process is primarily based on consensus. With such a diversity of membership, it is extremely difficult for members to reach unanimous views on substantive issues. This partly explains why 'critical mass' was introduced over the deliberations on sectoral liberalisation. Thus the APEC modality of voluntary measures, while both unique and popular among APEC members, has yet to demonstrate that it can produce meaningful results over time. 
- Shaky foundations. The developing members look to APEC for economic cooperation while the developed members appear to be single-minded about market opening. Dominated by trade and investment agendas and frustrated with the slow progress on ecotech, the developing members are getting more suspicious of the developed members' commitment to carrying out the ecotech agenda. The two sides have not had sufficient time to build up the trust and understanding needed to advance the APEC agenda hand-in-hand.

- Lack of focus. There are 15 areas in APEC's TILF agenda, and 13 areas in the ecotech agenda. ${ }^{6}$ Almost each area has its own expert group/ working group and work program. This adds up to a daunting amount of work. In addition, APEC has on its agenda an enormous number of other items such as EVSL, IAPs, CAPs, emergency preparedness, financial stability, electronic commerce, energy, environment and population, infrastructure, $\mathrm{ABAC}$, women, youth and civil society, as well as reviews of the economic outlook. In fact APEC has evolved into a dinosaur that can be hardly controlled and made manageable.

\section{RATIONALE FOR CHINA'SADMISSION}

China joined APEC in 1991. At that time it considered APEC as an 'informal, loose forum' that engaged in promoting dialogue and economic cooperation among its members. Being a non-member of the WTO or any other regional arrangement, China viewed APEC as an important venue for developing and deepening consultation and cooperation activities with the major trading partners in the region.

There are a number of important factors that determine China's stands on APEC. First of all, although APEC has not been a venue for ameliorating serious points of tension between individual members, it has provided a venue through which officials are able to cooperate in a constructive fashion on a broad range of work programs. APEC meetings also afford leaders and ministers the opportunity to convene separate bilateral meetings to discuss broader issues separate from the APEC agenda (Janow 1997). ${ }^{7}$ This has proven extremely important in the post-Tiananmen period, when President Jiang Zemin had the chance to meet regularly with President Clinton and other APEC leaders to exchange views on matters of common interest and concern. Second, the Asia Pacific region, which is the foothold of China's open-door policy, plays a pivotal role in China's foreign economic and trade relations. In 1995, China's trade with APEC members reached US $\$ 206.2$ billion, accounting for 73 per cent of China's total trade. Among China's major trade partners, all top five economies are APEC members. With respect to investment, 76 per cent of China's foreign direct investment was from APEC members. This trend has been reinforced in subsequent 
years with the deepening of regional economic integration. ${ }^{8}$ Third, being a nonmember of WTO, China for the first time participated on an equal footing in trade and investment policy deliberations. Meanwhile, China strives to use this platform to defend itself against US bilateral trade approaches towards China. The principle of non-discrimination, of which a compromise was reached at the last stage in Osaka, was considered a remarkable achievement. This constitutes an important leverage in underwriting China's most-favoured nation status.

\section{AIMINGHIGH}

Recognising the irreversible trend of globalisation and the need to maintain an open international trading environment, China has taken a positive stand on APEC's trade and investment agenda. It considers APEC's overall direction as consistent with the spirit of the $15^{\text {th }}$ Party Congress, national policy on reform and further opening up of the economy. Since its admission to APEC, China has reduced its average tariff level remarkably, from 40.3 per cent in 1992 to 17 per cent in 1998. It has made a commitment to reduce its average industrial tariffs to 10.8 per cent by 2005 , the weighted average to 6.6 per cent, and to eliminate tariffs on 185 information technology products. Meanwhile, many non-tariff measures have been removed, allowing more foreign financial institutions to open branches in China; active participation of foreign firms in commercial retailing, power generation and oil and gas exploration has been encouraged; the investment regime has been streamlined to make it more business-friendly; and the intellectual property rights enforcement system and competition policy legislation have been strengthened.

Nevertheless, China is still at the early stages of reform. The government, headed by President Jiang Zemin and Premier Zhu Rongji, is facing great challenges at home. Tremendous efforts have had to be made to slash the bloated government bureaucracy, to stop the money hemorrhaging from state enterprises, to overhaul the antiquated financial system, and to resist rising pressure for a renminbi devaluation. Moreover, the government has to create in an expeditious fashion a social security net to protect the alarming number of workers laid off due to state-owned enterprise restructuring. At the same time, they have to guard against the traditional leftists who vehemently vow to steer China off its reform course. These problems restrain China from making more positive contributions towards APEC's liberalisation process. Nonetheless, since China has adopted an open-door policy as its state policy, it will continue to participate in APEC activities in a positive manner. This is a unique platform from which China can express its opinions on the world's new economic order. China has offered to host the APEC meeting in 2001. On past experience, the host government, regardless of its previous stance, is usually very cooperative and constructive in making its year at the helm of APEC a successful one. 


\section{INTERAC'TIONS WITH CHINA}

Judging from the mechanism and functions of APEC, China is unlikely to obtain from APEC badly needed 'hardware' such as capital, technology and managerial skills. But APEC may act as an information source for China, a platform for policy discussion, and a stimulant for pursuing more liberal international trade and investment policies. In this context, APEC is valuable to China in providing 'software' to guide future economic development.

In reality, the impact of APEC is obvious. When drafting long-term plans for trade and investment, Chinese officials are increasingly conscious of President Jiang's commitment to APEC's goal of free and open trade and investment by the year 2020, and amend their plans accordingly. The ongoing APEC process is also exerting a direct influence on China's policy-making process. One example is in the area of government procurement, which is a new concept to China. Through hosting training programs and exchanging views with other member economies, China has gradually recognised the value of a sound government procurement system and has begun to initiate its own government procurement laws and practices in accordance with APEC's 'Non-Binding Principles on Government Procurement' and the practices in APEC member economies. Now a special task force has been established and relevant institutional work is underway. A draft law governing the operation of government procurement has entered into the second reading of China's legislative body, the Chinese People's Congress. None of these actions could have occurred without the impetus provided by APEC. Undoubtedly, efforts of this nature will help accelerate China's integration into the world economy.

In the past, China regarded APEC's trade and investment agenda as a nonbinding, long-term process, and drafted its IAPs in that fashion. But this perception was strongly challenged with the rapid evolution of the EVSL process. China's domestic industries have begun to face pressure from foreign competition. Affected industries have vehemently called for prolongation of protection. This has presented the government with a dilemma. On the one hand, China -unlike small economies such as Hong Kong and Brunei-has, over the years, invested heavily in and developed a relatively complete industrial system covering all sectors of the economy. But to date most of those industries are known for overstaffing, obsolete equipment and technology, high costs and low efficiency, and are not competitive with their foreign counterparts. The government is not prepared to absorb the sunk cost and shoulder the social welfare expenses that would come with opening up the economy. On the other hand, it has realised that non-action is equally suicidal, as moribund industries are using precious resources each year. With its state enterprises undergoing reform, China therefore seeks a longer phasing-in period for EVSL proposals. While the outcomes remain to be seen, EVSL has indeed changed China's perceptions of APEC and forced it to amend its even-paced approach towards APEC's trade and investment agenda. 


\section{LOOKINGAHEAD}

APEC is now at a critical moment. In recent years, it has made remarkable progress in defining its goals and promoting its trade and investment agenda. Its firm commitment to free and open trade and investment has greatly improved the business climate in the Asia Pacific region. APEC's principles of WTOconsistency and non-discrimination have strengthened the international trading system and had a significant impact upon the development of regionalism. Its pioneering trade and investment agenda ensures APEC adds value to state-ofthe-art issues. Through wide exchange of experience and information, APEC members have developed a growing sense of 'APEC community', enhanced mutual understanding, and a sound foundation has been laid for future actions. The annual APEC summit, highly valuable to all its members, has become one of the most prominent events in the world and has attracted the attention of the international community.

Nevertheless, APEC has obvious shortfalls and is increasingly facing a credibility problem. To cope with changing circumstances, APEC must further consolidate its position on trade and investment, develop a more effective implementation mechanism, and find better ways to carry out its ecotech agenda. In addition, its leaders should act together to produce focused and results-oriented outcomes, in making responsible decisions about important issues in the region. APEC also needs to work more closely with the business community and broaden its outreach to involve a wider segment of the business sector. These are crucial elements in ensuring healthy and sustainable development from APEC's future endeavours.

\section{NOTES}

1 Merit Janow, Professor in the Practice of International Trade of Columbia University, provides details of the historical background and rationale for the setting up of APEC in her recent paper (see Janow 1997).

2 The 15 sectors identified by APEC ministers and leaders in Vancouver in 1997 included: environmental goods and services, fish and fish products, forest products, medical equipment and instruments, energy, toys, gems and jewelry, chemicals, telecommunications mutual recognition arrangement, oilseeds and oilseed products, food, natural and synthetic rubber, fertilisers, automotive, civil aircraft. The first sectors are classified as 'fast-track' sectors.

3 See introductory material Asia-Pacific Economic Cooperation 1998, and Selected APEC Documents 1998, both published by the APEC secretariat.

4 See APEC Introduction available online at http://www.apecsec.org.sg/ 97brochure/97brochure.html 
5 In his speech addressed to the Council on Foreign Relations, President Clinton called the economic crisis the 'biggest financial challenge facing the world in a half century'. The New York Times, 14 September 1998.

6 OAA specifies that ecotech should be conducted on the basis of 'mutual respect and equality, mutual benefit and assistance, constructive and genuine partnership and consensus building'. Its purpose is to attain sustainable growth and equitable development in the Asia Pacific region, while reducing economic disparities among APEC economies and improving economic and social well being.

7 The 15 areas in trade and investment liberalisation and facilitation include: tariffs, non-tariff measures, services, investment, standard and conformance, customs procedures, intellectual property rights, competition policy, government procurement, deregulation, rules of origin, dispute mediation, mobility of business people, implementation of the Uruguay Round outcomes, information gathering and analysis. The 13 areas under ecotech include: human resources development, industrial science and technology, small and medium enterprises, economic infrastructure, energy, transportation, telecommunications and information, tourism, trade and investment data, trade promotion, marine resources conservation, and agricultural technology.

8 According to China's customs statistics of 1997, China's trade with APEC members reached US $\$ 240.2$ billion, accounting for 73.9 per cent of its total trade. Foreign direct investment (FDI) from APEC members stood at US\$37.7 billion, accounting for 83.7 per cent of the total FDI it attracted during the whole year. The top six investors - Hong Kong, Japan, Chinese Taipei, United States, Singapore, and the Republic of Korea-were all APEC members.

\section{REFERENCES}

Janow, Merit, 1997. 'APEC: an assessment,' Northwestern Journal of International Law and Business, January.

Pacific Economic Cooperation Council (PECC), 1996. 'Assessment of MAPA', published by PECC for the APEC Secretariat, Singapore.

— 1995. Survey of Impediments to Trade and Investment in the APEC region, published by PECC for the APEC Secretariat, Singapore. 